\title{
Allelic Relationship between Lr9 and the Leaf Rust Resistance Gene in Kharchia Local Mutant of Wheat
}

\author{
Navjot Kaur Dhillon $^{{ }^{*}}$, Harcharan Singh Dhaliwal ${ }^{2}$ \\ ${ }^{1}$ Department of Plant Breeding and Genetics, Punjab Agricultural University, Ludhiana, India; ${ }^{2}$ Akal School of Biotechnology, Baru \\ Sahib, Himachal Pradesh, India. \\ Email:*dhillon.navjot@gmail.com
}

Received August $9^{\text {th }}, 2011$; revised September $30^{\text {th }}, 2011$; accepted October $30^{\text {th }}, 2011$.

\begin{abstract}
To confirm allelic relationship between Lr9 and the leaf rust resistance gene in KLM4-3B, genetics of resistance was studied using crosses $\left(\right.$ WL711 + Lr9) $\times$ WL711 and (WL711 + LrKLM4-3B) $\times$ WL711. The F ${ }_{2}$ populations in cross $($ WL711 + Lr9) $\times$ WL711 and $($ WL711 + LrKLM4-3B) $\times$ WL711 segregated in ratio of 3:1 for disease reaction at seedling stage against pathotype 77-5 of leaf rust. This suggests that rust resistance in these stocks are under the control of single dominant genes. Further, to study allelic relationship between Lr9 and LrKLM4-3B, $F_{2}$ population of the cross $($ WL711 + LrKLM4-3B) $\times($ WL711 + Lr9) was studied. A segregation ratio of 15:1 implies that the two genes Lr9 and LrKLM4-3B are non-allelic genes.
\end{abstract}

Keywords: Lr9, Isogenic Lines, Non-Allelic Genes

\section{Introduction}

It is imperative to stabilize the wheat production by reducing the losses due to various diseases including leaf rust, stem rust, yellow rust, Karnal bunt etc. Among the diseases, leaf rust caused by Puccinia recondita Roberage ex. Desmaz f.sp. tritici is one of the most important and devastating foliar diseases of wheat which cause significant yield losses all over the world [1-8]. In all regions in which wheat is grown, rusts have caused periodic severe epidemics [9]. The rust accelerates foliage senescence reducing cumulative light interception of the crop which leads to reduced dry matter production [10]. Breeding for resistance against leaf rust is an economical, efficient and environmentally safe control measure to reduce these losses [11]. Development of disease resistant varieties is one of the most economical methods of control of diseases like leaf rust. However, growing of rust resistant varieties having single gene for resistance results in rapid evolution of virulent biotypes of the pathogen, thereby making the resistance gene ineffective and the variety susceptible to rust. One of the ways to develop varieties with durable rust resistance is to pyramid the genes for resistance in a single variety [12]. It is difficult to pyramid two or more disease resistance genes through con- ventional means, particularly where the resistance genes in question are effective against all the prevalent pathotypes. However, recent advances in molecular biology have made it possible to pyramid several genes in single line using marker assisted selection (MAS). Tagging of genes with molecular markers is pre-requisite for MAS [13].

A number of rust resistance genes, including those for leaf rust resistance, have been transferred from wild relatives of wheat into cultivated wheats $[14,15]$. In India, from the analyses of 2630 samples collected from 17 states, one union territory and Nepal from 2005 to 2008, 31 races were identified among which eight were new [16]. Most of these could not, however be exploited commercially because of extensive linkage drag. One of the leaf rust resistance genes, $\operatorname{Lr} 9$ transferred from Aegilops umbellulata [17] and located on chromosome 6BL, has no undesirable effect associated with it [18]. This gene is effective against all the races of leaf rust currently prevalent in Northern India. Similarly, another leaf rust resistance gene identified in (Kharchia local mutant KLM43B) is also effective against all the prevalent leaf rust pathotypes in Northern India. In the absence of virulence, capable of differentiating $\operatorname{Lr} 9$ and KLM4-3B in the In- 
dian subcontinent KLM4-3B has been suspected to be $L r 9$ rather than an induced mutant of Kharchia local [19].

High density molecular maps have been constructed in several crops including rice, maize, tomato and Triticum $[20,21]$ and a number of genes of economic importance have been tagged with series of molecular markers [22, 23]. Molecular markers closely linked to the genes for rust resistance can be used not only for establishing allelic relationships among resistant sources but also for their pyramiding using marker assisted selection (MAS).

\section{Material and Method}

\subsection{Disease Reaction Studies}

Single spore culture of $P$ recondita f.sp. tritici variants 77-5 (maintained on Agra local) were used for identification of $F_{2}$ seedling resistance genes.

\subsection{Raising of Seedlings}

Seeds of the parents (WL 711, KLM4-3B and Thatcher + Lr9) were sown along with $F_{2}$ populations of the three crosses in bread boxes containing a mixture of farmyard manure and sandy loam soil in equal proportions. Agra local was also sown as susceptible check. The seedlings were raised in glass house maintained at a temperature of $25^{\circ} \mathrm{C} \pm 1{ }^{\circ} \mathrm{C}$. Relative humidity above 80 per cent was maintained by using desert cooler. The bread boxes were watered every day to maintain vigour of the seedlings.

First leaf of the seven day old seedling was inoculated with homogeneous mixture of appropriate rust culture and talc, keeping inoculum density of $6-10$ urediospores per microscopic field at a magnification of $100 \mathrm{x}$ under light microscope. After inoculation the seedlings were incubated at 100 percent relative humidity for 16 hours. These seedlings were then transferred to growth chambers.

\subsection{Scoring the Infection Types}

Fourteen days after inoculation, the infection type on the seedlings was scored using a modification of the scale given by Stakman [24]. The seedlings showing infection type $0,1,2$ and $\mathrm{X}$ were classified as resistant, whereas those with infection types 3 to 4 were classified as susceptible.

Further, disease reaction of $\mathrm{F}_{2}$ population of three different crosses at adult stage were scored by using Modified Cobb Scale by Peterson [25].

\subsection{Statistical Analysis}

Simple Chi-square $\left(\chi^{2}\right)$ test was applied to fit appropriate genetic ratios in $F_{2}$ generation obtained from the three crosses (WL 711 + Lr9) $\times$ WL 711, (WL 711 + LrKLM4$3 \mathrm{~B}) \times \mathrm{WL} 711$ and $(\mathrm{WL} 711+\operatorname{Lr} 9) \times(\mathrm{WL} 711+$
LrKLM4-3B). Chi-square value was calculated using the following formula:

$$
\chi_{(n-1) \text { d.f. }}^{2}=\sum \frac{(\mathrm{O}-\mathrm{E})^{2}}{\mathrm{E}}
$$

where,

$n=$ Number of phenotypic classes.

d.f. $=$ Degree of freedom.

$\mathrm{O}=$ Number of observed plants in a phenotypic class.

$\mathrm{E}=$ Number of expected plants in a phenotypic class.

\section{Results and Discussion}

In the present investigation, to confirm the allelic relationship between the leaf rust genes $\operatorname{Lr} 9$ and the resistant gene in KLM4-3B, $\mathrm{F}_{2}$ generations of three crosses (WL $711+\operatorname{Lr} 9) \times \mathrm{WL} 711,(\mathrm{WL} 711+\operatorname{LrKLM} 4-3 \mathrm{~B}) \times \mathrm{WL}$ 711 and $(\mathrm{WL} 711+\operatorname{Lr} 9) \times(\mathrm{WL} 711+\operatorname{LrKLM} 4-3 \mathrm{~B})$ were studied. The results pertaining to these studies are presented here.

Results of the cross of isogenic line of the leaf rust resistant gene of KLM4-3B (LrKLM4-3B) with the recurrent parent, WL711 are presented in Tables 1 and 2. Out of $122 \mathrm{~F}_{2}$ plants, 86 were resistant and 36 susceptible to leaf rust pathotype 77-5. The infection type observed on resistant plants were $0,0,1,1^{+}, 2,2^{+}$. The segregation of $\mathrm{F}_{2}$ plants showed a good fit to $3: 1$ ratio $\left(\chi^{2}=1.32\right)$. This indicated that the $L r$ KLM4-3B is dominant.

In the second cross of isogenic lines of $\operatorname{Lr} 9$ with the recurrent parent, out of $126 \mathrm{~F}_{2}$ plants 89 plants were resistant and 37 were susceptible to the leaf rust pathotype 77-5 [Table 1]. The ratio of resistant to susceptible plants did not differ significantly from $3: 1\left(\chi^{2}=1.28\right)$. This indicated that $\operatorname{Lr} 9$ also behaves as dominant gene to pathotypes 77-5.

In the cross between isogenic lines carrying $\operatorname{Lr} 9$ and LrKLM4-3B, out of $101 \mathrm{~F}_{2}$ plants, 91 showed resistant reaction and 10 were susceptible to pathotype 77-5. This did not differ significantly from 15 resistant: 1 susceptible ratio (Table 1). This suggested that the two leaf rust resistant genes, $\operatorname{Lr} 9$ and $\operatorname{LrKLM} 4-3 \mathrm{~B}$, are non-allelic. The earlier studies have also shown that these two leaf rust genes are non-allelic [19]. $\operatorname{Lr} 9$ is an alien gene on chromosome 6BL translocation from Aegilops umbellata [17], whereas LrKLM4-3B was identified to be resistant to leaf rust [26]. Preliminary work carried out at the School of Biotechnology, Punjab Agricultural University has shown that the LrKLM4-3B is not a mutant gene as claimed earlier [26] but is associated with translocation involving chromosome 2BL (Dhaliwal and Harjit Singh, Pers.Commu.). These observations further support that these two genes are non-allelic.

\section{Conclusions}

Genetics of resistance studied of F2 population using 
Table 1. $F_{2}$ segregation for reaction to leaf rust pathotype $77-5$ in three different crosses.

\begin{tabular}{|c|c|c|c|c|c|c|c|c|c|c|}
\hline \multirow{2}{*}{$\begin{array}{l}\text { Sr. } \\
\text { No. }\end{array}$} & \multirow{2}{*}{ Crosses } & \multirow{2}{*}{$\begin{array}{l}\text { Total no. } \\
\text { of plants }\end{array}$} & \multicolumn{5}{|c|}{ Observed number of plants } & \multirow{2}{*}{ Expected ratio } & \multirow{2}{*}{$X^{2}$ (Cal.) } & \multirow{2}{*}{ Probability (P) } \\
\hline & & & Resistant $\left(0-2^{+}\right)$ & $3^{+}$ & $4^{-}$ & 4 & Total & & & \\
\hline 1. & $(\mathrm{WL711}+\operatorname{Lr}$ KLM4-3B $) \times \mathrm{WL711})$ & 122 & 86 & 14 & 4 & 18 & 36 & $3: 1$ & $1.32^{\mathrm{NS}}$ & $0.10-0.25$ \\
\hline 2. & $(\mathrm{WL711}+\operatorname{Lr} 9 \times \mathrm{WL711})$ & 126 & 89 & 16 & 2 & 19 & 37 & $3: 1$ & $1.28^{\mathrm{NS}}$ & $0.10-0.25$ \\
\hline 3. & $(\mathrm{WL} 711-\operatorname{Lr}$ KLM4-3B $) \times(\mathrm{WL} 711+\operatorname{Lr} r)$ & 101 & 91 & 5 & 2 & 3 & 10 & 15:1 & $2.29^{\mathrm{NS}}$ & $0.05-0.10$ \\
\hline
\end{tabular}

Table 2. Adult stage disease reaction of $F_{2}$ population.

\begin{tabular}{|c|c|c|c|c|c|c|}
\hline \multirow[t]{2}{*}{ Seedling reaction } & \multicolumn{2}{|c|}{$($ WL 711 + LrKLM4-3B) $\times$ WL711 } & \multicolumn{2}{|c|}{$(\mathrm{WL711}+\operatorname{Lr} 9) \times \mathrm{WL711}$} & \multicolumn{2}{|c|}{$($ WL711 - Lr KLM4-3B) $\times($ WL711+ Lr9) } \\
\hline & Adult reaction & Number of plants & Adult reaction & Number of plants & Adult reaction & Number of plants \\
\hline 0,$0 ;, ;$ & 0 & 75 & 0 & 79 & 0 & 86 \\
\hline $1,1^{+}, 2,2^{+}$ & TS & 5 & TS & 4 & TS & 1 \\
\hline \multirow[t]{2}{*}{ (R) } & $5 \mathrm{~S}$ & 9 & $5 \mathrm{~S}$ & 6 & $5 \mathrm{~S}$ & 4 \\
\hline & $10 \mathrm{~S}$ & 4 & $10 \mathrm{~S}$ & 4 & $10 \mathrm{~S}$ & 5 \\
\hline $3^{+}, 4$ & $40 \mathrm{~S}$ & 4 & $40 \mathrm{~S}$ & 7 & $40 \mathrm{~S}$ & 3 \\
\hline \multirow[t]{2}{*}{$(\mathrm{S})$} & $60 \mathrm{~S}$ & 26 & $60 \mathrm{~S}$ & 23 & $60 \mathrm{~S}$ & 2 \\
\hline & $80 \mathrm{~S}$ & 2 & $80 \mathrm{~S}$ & 3 & $80 \mathrm{~S}$ & - \\
\hline
\end{tabular}

crosses (WL711 + Lr9) $\times$ WL711 and (WL711 + LrKLM4$3 B) \times$ WL711 segregated in ratio of 3:1 for reaction to pathotype 77-5 of leaf rust. This suggested that rust resistance in these stocks is under the control, of single dominant genes. Further, to study allelic relationship between $L r 9$ and $L r K L M 4-3 B, \mathrm{~F}_{2}$ population of the cross $($ WL711 + LrKLM4-3B) $\times($ WL711 $+\operatorname{Lr} 9)$ was studied. A segregation ratio of 15:1 demonstrate that the two genes $L r 9$ and $L r K L M 4-3 B$ are two different non-allelic genes.

\section{REFERENCES}

[1] M. G. Eversmeyer and L. E. Browder, "Effect of Leaf and Stem Rust on 1973 Kansaswheat Yields," Plant Disease Reporter, Vol. 58, No. 5, 1974, pp. 469-471.

[2] R. G. Saini and A. K. Gupta, "Genes for Resistance to Brown Rust Puccinia recondita) in Wheat. II. Lr Genes in Frontana, WG138 and E6360," Cereal Research Communications, Vol. 7, 1979, pp. 289-291.

[3] D. Anand, R. G. Saini and A. K. Gupta, "Slow Leaf Rust Development Due to Combination of Some Genes in Wheat," Plant Disease Reporter, Vol. 3, 1988, p. 97.

[4] M. Seck, A. P. Roelfs and P. S. Teng, "Effect of Leaf Rust Puccinia recondite Triticii on Yield of Four Isogenic Wheat Lines," Crop Protection, Vol. 7, No. 1, 1988, pp. 39-43. doi:10.1016/0261-2194(88)90036-1

[5] K. V. S. Rao, J. P. Snow and G. T. Berggren, "Effect or Growth Stage and Initial Inoculum Level on Leaf Rust Development and Yield Loss Caused by Puccinia recondita f. sp. tritici," Journal of Phytopathology, Vol. 127, No. 3, 1989, pp. 200-210. doi:10.1111/j.1439-0434.1989.tb01130.x

[6] R. P. Singh, J. Huerta-Espino, W. Pfeiffer and P. F. Lo- pez, "Occurrence and Impact of a New Leaf Rust Race on Durum Wheat in Northwestern Mexico from 2001 to 2003," Plant Disease, Vol. 88, No. 7, 2004, pp. 703-708. doi:10.1094/PDIS.2004.88.7.703

[7] J. A. Appel, E. DeWolf, W. W. Bockus and T. Todd, "Kansas Cooperative Plant Disease Survey Report Preliminary Kansas Wheat Disease Loss Estimates," August 11, 2009. http:// www.ksda.gov/includes/document center/plant_protection/Plant\%20Disease20Reports/2009KS WheatDiseaseLossEstimates.pdf. Accessed 29 November 2010.

[8] G. V. Volkova, T. P. Alekseeva, L. K. Anpilogova, M. V. Dobryanskaya, O. F. Vaganova and D. A. Kol'bin, "Phytopathological Characteristics of Leaf Rust Resistance of New Winter Wheat Varieties," Russian Agricultural Sciences, Vol. 35, No. 3, 2009, pp. 168-171. doi:10.3103/S1068367409030112

[9] A. Vjyushkov, P. Malchikov and V. Syukov, "Breeding Genetic Improvement of Spring Wheat," Samara Agric Research Institute, Samara, 2008, p. 546.

[10] C. J. T. Spitters, H. J. W. Van Roermund, H. G. M. G. Van Nassau, J. Sohapur and J. Mesdag, "Genetic Variation in Partial Resistance to Leaf Rust in Winter Wheat. Disease Progress, Foliage Senescence and Yield Reduction," Biomedical and Life Sciences, Vol. 96, No. 1, 1990, pp. 3-15. doi:10.1007/BF01976602

[11] J. H. Espino, R. P. Singh, S. Germa'n, B. D. McCallum, R. F. Park, Q. W. S. Chen, C. Bhardwaj and H. Goyeau, "Global Status of Wheat Leaf Rust Caused by Puccinia triticina," Euphytica, Vol. 179, No. 1, 2011, pp. 143-160. doi:10.1007/s10681-011-0361-x

[12] I. Lowe, D. Cantu and J. Dubcovsky, "Durable Resistance to the Wheat Rusts: Integrating Systems Biology and Traditional Phenotype-Based Research Methods to 
Guide the Deployment of Resistance Genes," Euphytica, Vol. 179, No. 1, 2011, pp. 69-79. doi:10.1007/s10681-010-0311-Z

[13] L. Huang, L. Q. Zhang, B. L. Liu, Z. H. Yan, B. Zhang, H. G. Y. L Zhang and D. C. Liu, "Molecular Tagging of a Stripe Rust Resistance Gene in Aegilops Tauschii," Euphytica, Vol. 179, No. 2, 2011, pp. 313-318. doi:10.1007/s10681-010-0330-9

[14] M. Baum, E. S. Laguadah and R. Appels, "Wide Crosses in Cereals," Annual Review of Plant Physiology and Plant Molecular Biology, Vol. 43, 1992, pp. 117-143. doi:10.1146/annurev.pp.43.060192.001001

[15] Z. A. Pretorius and C. M. Bender, "First Report of Virulence for the Wheat Leaf Rust (Puccinia triticina) Resistance Gene Lr32 in South Africa," Plant Disease, Vol. 94, No. 3, 2010, pp. 381. doi:10.1094/PDIS-94-3-0381A

[16] S. C. Bhardwaj, M. Prashar, S. K. Jain, S. Kumar, Y. P. Sharma, "Physiologic Specialization of Puccinia Triticina on Wheat (Triticum Species) in India," Indian Journal of Agricultural Sciences, Vol. 80, 2010, pp. 805-881.

[17] E. R. Sears, "The Transfer of Leaf Rust Resistance from Aegilops umbellulata into Wheat," Brookhaven Symposia in Biology, Vol. 9, 1956, pp. 1-21.

[18] A. S. Soliman, E. Y. Heyne and C. O. Johnston, "Resistance to Leaf Rust in Wheat Derived from Chinese $A e$ gilops umbellulata Translocation Lines," Crop Science, Vol. 3, 1963, pp. 254-256. doi:10.2135/cropsci1963.0011183X000300030025x

[19] S. Harjit, H. S. Dhaliwal and K. S. Gill, "A New Leaf Rust Resistance Gene other than $\operatorname{Lr} 9$ in Kharchia Local Mutant KLM4-3B," Ann Wheat Newsl, Colorado State Univ, Vol. 40, pp. 145-46.
[20] K. M. Devos, T. Millan and M. D. Gale, "Comparative RFLP Maps of the Homoeologous Group-2 Chromosomes of Wheat, Rye and Barley," Theoretical and Applied Genetics, Vol. 85, No. 6-7, 1993, pp. 784-92. doi:10.1007/BF00225020

[21] F. Sacco, E. Y. Suarez and T. Naranjo, "Mapping of the Leaf Rust Resistance Gene Lr3 on Chromosome 6B of Sinvalocho MA Wheat," Genome, Vol. 41, No. 5, 1998, pp. 686-690.

[22] M. Mohan, S. Nain, A. T. G. B. Krishna, M. Y. Ano, C. R. Bhatia and T. Saski, "Genome Mapping, Molecular Markers and Marker-Assisted Selection in Crop Plants," International Crop Science Congress, Working Group on Genome Mapping and Marker Assisted Selection in Plant Breeding, New Delhi, 1996, pp. 999-1018. doi:10.1007/BF00222911

[23] G. Schachermayr, M. Messmer, C. Feuillet, H. Winzeler, M. Winzeler and B. Keller, "Identification of Molecular Markers Linked to the Agropyron Elongatum-Derived Leaf Rust Resistance Gene Lr24 in Wheat," Theoretical and Applied Genetics, Vol. 90, 1995, pp. 982-990.

[24] E. C. Stakman, D. M. Stewart and W. Q. Loegering, "Identification of Physiological Races of Puccinia graminis var. tritici," US Department of Agricultural Publications E617. USDA, Washington, DC, 1962.

[25] R. F. Peterson, A. B. Campbell and A. E. Hannah, "A Diagramatic Scale for Estimating Rust Intensity of Leaves and Stem of Cereals," Canadian Journal of Research, Vol. 26, 1948, pp. 496-500.

[26] R. N. Swahney, S. K. Nayar, S. D. Singh and L. B. Goel, "A New Source of Resistance to Leaf Rust of Wheat," Plant Disease Reporter, Vol. 63, 1979, pp. 1048-1049. 